\title{
Korelasi Health Belief dengan Kepatuhan Pembatasan Cairan dan Garam pada Pasien Penyakit Ginjal Kronik yang Menjalani Hemodialisa di Rumah Sakit Murni Teguh Medan
}

\author{
Kalvin Ginting ${ }^{1, a^{*}}$, Sutomo Kasiman ${ }^{2, b}$, Cholina Trisa Siregar ${ }^{3, c}$ \\ ${ }^{1}$ Program Studi Magister Keperawatan, Universitas Sumatera Utara, Medan 20155, Indonesia \\ ${ }^{2}$ Fakultas Kedokteran, Universitas Sumatera Utara, Medan 20155, Indonesia \\ ${ }^{3}$ Fakultas Keperawatan, Universitas Sumatera Utara, Medan 20155, Indonesia

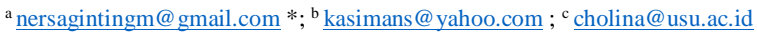 \\ * corresponding author
}

ARTICLE INFO

Keywords

Health Belief

Compliance

\begin{abstract}
Patients with Chronic Kidney Disease (hereinafter is referred to as $\mathrm{CKD}$ ) require special treatment for the medication recommended by doctors. Generally, individuals who know that they suffer from a disease, they will take more serious care for their health and take medication in accordance with doctors' recommendation. However, there are still many patients with CKD do not comply with the doctors' recommendation. Health belief is the belief adhered in undergoing medication will affect the believers' health. The objective of this research was to analyze the correlation of health belief with fluid and salt restriction compliance in patients with CKD undergoing hemodialysis. This research employed quantitative design with cross sectional method. There were 150 patients with CKD undergoing hemodialysis in total that were taken as the samples. This research was conducted at Murni Teguh Hospital, Medan. The samples were selected by applying total accidental technique. The data were collected through questionnaires, and the analysis was made by using Pearson test. The results of Pearson test on the correlation of health belief with patients' fluid and salt restriction compliance demonstrated value of $p=0.000$. It indicated that health belief are correlated with the fluid and salt restriction compliance of patients with CKD undergoing hemodialysis. It is recommended that nurses improve their education quality and frequency by paying attention to patients.
\end{abstract}

\section{Pendahuluan}

Penyakit ginjal kronik (CKD) stadium $\mathrm{V}$ merupakan kondisi menurunnya fungsi ginjal selama periode berbulan-bulan atau bertahun-tahun [1]. Penurunan fungsi ginjal dapat diakibatkan oleh kelainan yang ada pada ginjal atau disebabkan oleh penyakit lain [2]. Penyakit ginjal kronik di dunia saat ini mengalami peningkatan dan menjadi masalah kesehatan yang serius. Data Global Burden of Disease tahun 2010 menunjukkan bahwa penyakit ginjal kronis merupakan penyebab kematian peringkat ke 27 di dunia tahun 1990 dan meningkat menjadi urutan ke 18 pada tahun 2010. Lebih dari dua juta penduduk di dunia mendapatkan perawatan dengan dianalisis atau transplantasi ginjal dan hanya sekitar $10 \%$ yang benar-benar mengalami perawatan tersebut. Sepuluh persen penduduk di dunia mengalami penyakit ginjal kronis dan jutaan meninggal setiap tahun karena tidak mempunyai akses untuk pengobatan [3]. 
Data yang diperoleh dari Indonesian Renal Registry menunjukkan bahwa jumlah pasien baru penyakit ginjal kronik di Indonesia yang mengikuti terapi dialysis pada tahun 2014 yakni sebanyak 17.193 dan pasien yang aktif mengikuti terapi dialysis sebanyak 11.689. Pada tahun 2015 jumlah pasien baru sebanyak 21.050 dan jumlah pasien yang aktif dengan dialysis sebanyak 30.554. Pada tahun 2016 jumlah pasien baru sebanyak 25.446 dan pasien yang aktif dialysis sebanyak 52.835. Dan pada tahun 2017 jumlah pasien baru sebanyak 30.831 dan pasien yang aktif dialysis sebanyak 77.892 [4].

Salah satu masalah besar yang berkontribusi pada kegagalan hemodialisis adalah masalah kepatuhan pasien. Kepatuhan pasien dalam merubah perilaku seseorang dalam mendapatkan pengobatan, mengikuti diet, dan melaksanakan perubahan gaya hidup sesuai dengan rekomendasi pemberi pelayanan kesehatan [5]. Ketidakpatuhan terhadap pengobatan dapat menjadi penyebab kematian yang lebih besar pada pasien penyakit ginjal kronik. Sehingga diperlukan strategi untuk meningkatkan pengetahuan ataupun pemahaman dan juga perilaku kesehatan sehingga nantinya dapat terjadi peningkatan kondisi klinis pasien. Perilaku kesehatan yang berhubungan dengan penyakit ginjal kronik dapat dipelajari dengan menggunakan Health Belief Model (HBM). HBM adalah teori perubahan perilaku tingkat individu [6].

Kepatuhan pasien ini dipengaruhi oleh Health Belief yang berakar pada teori kognitif seperti keyakinan dan sikap yang berkaitan dengan proses berpikir dalam pengambilan keputusan untuk bertindak dengan cara tertentu. Pasien yang berpikir penyakit ginjal yang dideritanya dapat mengancam kesehatannya sewaktu-waktu jika tidak membatasi cairan dan garam dari asupan makanan dan minuman [7].

\section{Metode}

Dalam Penelitian ini menggunakan metode penelitian kuantitatif dengan metode cross sectional yang mempelajari dinamika korelasi antara faktor-faktor resiko dengan efek, dengan cara pendekatan, observasi atau pengumpulan data sekaligus pada suatu saat yaitu variabel dependen dan variabel independen diobservasi pada saat yang bersamaan. Dalam hal ini hubungan yang dianalisis adalah hubungan antara variabel independen yaitu health belief dengan variabel dependen kepatuhan pembatasan cairan dan garam pada pasien yang menjalani hemodialisia. Penelitian ini dilaksanakan di Rumah Sakit Murni Teguh Medan, Jalan Jawa No. 2, MedanTimur, Kota Medan, Sumatera Utara pada hari Senin sampai Rabu tanggal 19-21 Agustus 2019 selama 3 hari.

Adapun yang menjadi responden dari penelitian ini adalah:

a. Pasien hemodialisa regular

b. Keluarga yang mendampingii saat terapi hemodialis

\section{Hasil dan Diskusi}

\section{Hubungan Health Belief dengan Kepatuhan Pasien Hemodialisis Dalam Pembatasan Cairan dan Garam}

Hasil penelitian pada menunjukkan Health belief pasien hemodialsisis di Rumah Sakit Murni Teguh Medan tahun 2019 rata-rata health belief tinggi adalah 112 (74,7\%) sedangkan health belief rendah adalah 38 (25,3\%). Hasil penelitian menunjukkan bahwa dimensi health belief yang meliputi keyakinan individu terhadap kerentanan dirinya terhadap komplikasi penyakit (perceived susceptibility), keyakinan individu mengenai keseriusan penyakitnya (perceived severity), keuntungan yang dipersepsikan individu dalam menampilkan perilaku sehat (perceived benefit), hambatan yang dipersepsikan individu dalam menjalani perilaku yang dianjurkan (perceived barrier), keyakinan individu mengenai adanya tanda yang menyebabkan seseorang untuk bergerak kea rah pencegahan (cues to action) dan keyakinan individu mengenai kemampuan yang dimiliki untuk melakukan sesuatu (self efficacy) berhubungan dengan perilaku kepatuhan pasien gagal ginjal kronik yang menjalani hemodialisis. sedangkan health belief rendah adalah $38(25,3 \%)$. 
Tabel 1. Deskripsi Frekuensi Health Belief Pasien Hemodialisis di Unit Hemodialisis RS Murni Teguh tahun 2019

\begin{tabular}{ccccc}
\hline No. & & Health Belief & Frekuensi & \% \\
\hline 1. & Tinggi & & 112 & 74.7 \\
2. & Rendah & & 38 & 25.3 \\
\hline & & Jumlah & 150 & 100.0 \\
\hline
\end{tabular}

Keyakinan pasien tinggi karena tingkat pendidikan sudah tinggi dan sudah mendapat penjelasan dari dokter dan perawat, hal ini sejalan dengan pendapat Notoadmotjo (2014) semakin tinggi pendidikan individu semakin cepat memperoleh pengertian ataupun memahami informasi yang diberikan tenaga kesehatan. Keyakinan individu terhadap kerentanan dirinya terhadap komplikasi penyakit (perceived susceptibility) pada pasien gagal ginjal. Komplikasi ini berkaitan dengan kelebihan cairan dan elektrolit yang dapat mengakibatkan kematian pada penderita gagal ginjal kronik [8].

Keuntungan yang dipersepsikan individu dalam menampilkan perilaku sehat (perceived benefit) akan mempengaruhi tingkat kepatuhan pasien. Hasil wawancara pada pasien penyakit ginjal kronik menyatakan bahwa pasien yang patuh terhadap pembatasan cairan dan diet dikarenakan telah mengalami pengalaman bahwa dengan ketidakpatuhan, pasien akan mengalami keluhan seperti edema dan sesak. Keluhan ini akan berkembang menjadi penyakit penyerta apabila tidak ditangani dengan perubahan perilaku ke arah yang lebih baik. Maka dari itu, pasien cenderung akan mulai patuh guna menghindari hal tersebut, sehingga akan mempengaruhi kualitas hidupnya. Hambatan yang dipersepsikan individu dalam menjalani perilaku yang dianjurkan (perceived barrier) pada pasien penyakit ginjal kronik mempengaruhi tingkat kepatuhan pasien.

Hasil frekuensi kepatuhan pasien hemodialsis dalam pembatasan cairan dan garam di RS Murni Teguh Medan tahun 2019 adalah mayoritaspPatuh adalah 106 (70,7\%) sedangkan tidak patuh sebanyak $44(29,3 \%)$.

Tabel 2. Deskripsi Frekuensi Kepatuhan Pasien Hemodialisis Dalam Pembatasan Cairan dan Garam di Unit Hemodialisis RS Murni Teguh tahun 2019

\begin{tabular}{crrcc}
\hline No. & & Kepatuhan Pasien & Frekuensi & \% \\
\hline 1. & Patuh & & 106 & 70.7 \\
2. & Tidak patuh & 44 & 29.3 \\
\hline & & 150 & 100.0 \\
\hline
\end{tabular}

Pada hasil penelitian yang ditunjukkan pada tabel 2 yakitu Hubungan Health belief dengan kepatuhan pasien dalam pembatasan cairan dan garam pada pasien hemodialisis di RS Murni Teguh Medan tahun 2019 diperoleh nilai p-value 0,000. Menurut penelitian Patel, Sachan, Nischal, et al.(2012) menyatakan bahwa pasien PGK yang menjalani hemodialisis dari aspek psikologis kemungkinan dapat mempengaruhi perilaku patuh (compliance) dalam membatasi asupan cairan. yang akan mempengaruhi IDWG pasien.

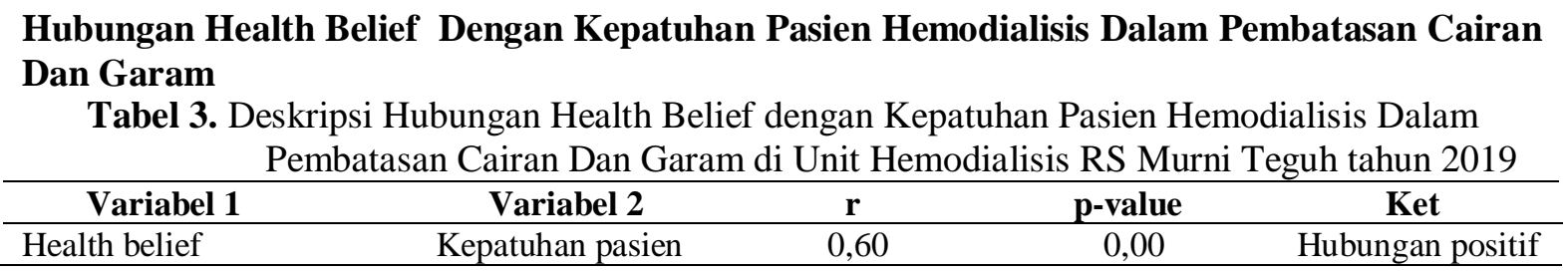

Pasien penyakit ginjal kronik yang menjalani hemodialisis rutin idealnya memperhatikan ada tidaknya haluaran urine sebagai acuan dasar agar dapat menentukan jumlah asupan cairan per hari. Tingginya jumlah pasien yang patuh terhadap indikator menghindari hal yang dapat meningkatkan asupan cairan menunjukkan bahwa pasien cenderung sudah lebih baik untuk mengontrol asupan cairan lain selain dari minum, seperti buah-buahan yang mengandung banyak 
air dan makanan pedas. Namun, pada saat tertentu pasien akan meningkatkan asupan cairan jika sudah mendekati jadwal untuk cuci darah yaitu 1-2 hari sebelum jadwal rutin cuci darah.

Pengontrolan terhadap hal-hal yang dapat meningkatkan asupan cairan dapat dipengaruhi oleh keyakinan pasien terhadap hambatan atau rintangan yang dihadapi (perceived barrier). Pasien yang patuh menunjukkan perilaku kontrol yang baik terhadap hambatan dari perilaku yang dianjurkan dalam pembatasan asupan cairan.

Tingginya jumlah pasien yang patuh terhadap indikator menghindari hal yang dapat meningkatkan asupan cairan menunjukkan bahwa pasien cenderung sudah lebih baik untuk mengontrol asupan cairan lain selain dari minum, seperti buah-buahan yang mengandung banyak air dan makanan pedas. Selain itu, faktor lama nya pasien HD juga mempengaruhi kepatuhan pasien karena sudah memperoleh edukasi dan informasi tentang hemodialisis dari perawat dan dokter. Namun, pada saat tertentu pasien akan meningkatkan asupan cairan jika sudah mendekati jadwal untuk cuci darah yaitu 1-2 hari sebelum jadwal rutin cuci darah. Pengontrolan terhadap halhal yang dapat meningkatkan asupan cairan dapat dipengaruhi oleh keyakinan pasien terhadap hambatan atau rintangan yang dihadapi (perceived barrier). Pasien yang patuh menunjukkan perilaku kontrol yang baik terhadap hambatan dari perilaku yang dianjurkan dalam pembatasan asupan cairan.

Perilaku kontrol yang baik terhadap pembatasan asupan cairan dapat dipengaruhi oleh pemberian konseling diet dan cairan. Maka dari itu, pemberian konseling diet dan cairan setiap kali pasien menjalani hemodialisis perlu dilakukan. Hal ini sesuai dengan penelitian Tanujiarso, Ismonah dan Supriyadi (2014) yang menunjukkan bahwa pemberian konseling diet cairan terbukti efektif terhadap pengontrolan IDWG pada pasien GGK yang menjalani HD. Konseling diet dan cairan dapat melibatkan peran serta keluarga karena semakin tinggi dukungan sosial, maka semakin tinggi pula pasien GGK berperilaku patuh terhadap pembatasan cairan. Hal ini sejalan dengan penelitian Andriani, Chanif, dan Rosidi (2013) yang menunjukkan terdapat hubungan yang signifikan antara dukungan sosial terhadap kepatuhan pembatasan cairan pada pasien GGK yang menjalani hemodialisis.

\section{Kesimpulan}

Dari hasil penelitian ini menunjukkan bahwa:

1. Health belief pasien hemodialsisis di RS Murni Teguh Medan tahun 2019 rata-rata health belief tinggi adalah $112(74,7 \%)$ sedangkan health belief rendah adalah 38 (25,3\%).

2. Kepatuhan pasien hemodialsis dalam pembatasan cairan dan garam di RS Murni Teguh Medan tahun 2019 rata-rata Patuh adalah 106 (70,7\%) sedangkan tidak patuh sebanyak 44 (29,3\%).

3. Terdapat hubungan yang positif health belief dan kepatuhan pasien bersifat positif.

\section{Saran}

\section{Bagi pelayanan keperawatan}

Hasil penelitian health belief dan budaya dengan kepatuhan pembatasan cairan dan garam pada pasien hemodialysis diharapkan dapat menjadi informasi tambahan bagi pelayanan keperawatan dalam memberikan asuhan keperawatan dan mengubah budaya pasien yang tidak baik bagi serta pembatasna cairan dan garam pada pasien hemodialisis.

\section{Bagi pendidikan keperawatan}

Hasil penelitian ini dapat menjadi salah satu materi tambahan dalam pembelajaran dalam penanganan masalah kepercayaan pasien terhadap kondisi kesehatannya dan mengenali budaya makan pasien dengan penyakit gagal ginjal kronis.

\section{Bagi peneliti keperawatan}

Hasil penelitian ini diharapkan dapat menjadi rujukan penelitian selanjutnya dan disarankan untuk menggunakan instrumen yang berbeda dalam mengukur health belief dan budaya pasien yang mengalami gagal ginjal kronis. 


\section{Referensi}

[1] Sarafino., \& Edward P. (2012). Health Psychology : Biopsychosocial Interactions (Fifth edition), hon wiley \& Sons Inc

[2] Mutaqin (2011). Asuhan Keperaatan Gangguan System Perkemihan. Jakarta: Salemba Medika

[3] Kemenkes RI (2017). Badan Penelitian dan Pengembangan Kesehatan. Riset Kesehatan Dasar (RISKESDAS).

[4] Indonesian Renal Registry (IRR), 2017. $9^{\text {th }}$ Report Of Indonesian Renal Registry (2016). Perhimpunan Nefrologi Indonesia (PERNEFRI).

[5] WHO (2013). How Can We Achieve Global Equity in Provision of Renal Replacement Theraphy Bull.

[6] Becker M. (2014). The Health Belief Model and Personal Hemalth Behavior. New Jersey: Slack Inc.

[7] Nursalam (2008). Asuhan Keperawatan pada Pasien dengan Gangguan Sistem Perkemihan. Edisi Pertama. Jakarta : Salemba Medika

[8] Swansburg, C. R. (2011). Pengembangan Staf Keperawatan: Suatu Pengembangan Sumber Daya Manusia. Jakarta: EGC

[9] Dewi, I.G.A.P.A (2011). Hubungan Tingkat Kepatuhan Paisen Terhadap Derajat Edema Pada Pasien GGK. Tesis. Universitas Indonesia

[10] Bart S. (2014). Psikologi Kesehatan. Jakarta: PT. Gramedia Widia Sarana Indonesia.

[11] Fisher A. (2015). Developmen of Fluid Assessment Tool To Acid Nursing Assessment Of Dry Weight.Poster At Brithish Renal Society Conference 